\title{
A TUDÁSMENEDZSMENT FEJLŐDÉSI SZAKASZAINAK TETTENÉRÉSE A MAGYAR ÜZLETI TANÁCSADÁS PIACÁN
}

A 2008-as gazdasági válság a menedzsmentdöntések homlokterébe helyezte a tudástóke-befektetéseket, aminek következtében a tudásmenedzsment szembetúnóen dinamikus fejlődésnek indult. A fejlôdés azonban globális szinten másfajta intenzitást mutat, mint Magyarországon. A szerzó kutatása ezeket a különbségeket igyekszik feltárni a magyar üzleti tanácsadó cégek tudásmenedzsment-gyakorlatán keresztül. A fejlódéstörténetet három részre bontva vizsgálta: rendszer, stratégia és versenyképesség szintjén. A magyar vezetési tanácsadók tudásmenedzsment-gyakorlatáról megállapítható, hogy komoly szakmai munka folyik a vizsgált vállalatok mindegyikénél, azonban kivétel nélkül van még továbbfejlôdési lehetôség a tudás menedzselésében.

Kulcsszavak: tudásmenedzsment evolúció, tudásmenedzsment stratégia, vezetési tanácsadás, tanácsadói piac

A szolgáltatások igen változatos formában jelennek meg napjaink gazdaságában, szinte már nem is különálló szolgáltatásokról és termékekról, hanem inkább termék-szolgáltatás kombinációk piacáról beszélhetünk. A termelővállalatok ennélfogva elválaszthatatlanok a szolgáltatóvállalatoktól, ez rengeteg problémát vet fel akkor, amikor azt szeretnék meghatározni, hogy mely vállalatok tartoznak a szolgáltató szektorba? Véleményem szerint a maradékelven alapuló megközelítés a legkézenfekvőbb, amikor úgy határozzuk meg a tercier szektort, hogy mi nem tartozik bele (pl. bányászat, mezőgazdaság, építészet, fémipar). Az effajta csoportosítás egy reziduális szektort képez, amely gyakorlatilag lefedi a szóban fogó tercier szektorban tevékenykedő vállalatok lajstromát. Ez a terminológia csupán egy a sok közül, ugyanis további kategóriák jelennek meg piaci és nem piaci szolgáltatások szerinti bontásban, marketingszemléletú bontásban, B2B és B2C szerinti bontásban vagy akár termelői-fogyasztói szolgáltatások (Papp, 2010) bontásában.

A szolgáltató szektor relevanciáját jól mutatják azok a statisztikák ${ }^{1}$, melyek szerint Magyarországon a GDP 66,6\%-át a szolgáltatói-parágak termelték meg 2008-ban. Ez a szám ijesztóen soknak túnhet, de nemzetközi viszonylatban még mindig elmaradottnak számítunk az ugyanígy GDP-viszonylatban vizsgált $77,2 \%$-os USA, 77,5\%-os Franciaország vagy 75,4\%os Egyesült Királysággal szemben. Ezzel párhuzamos tendencia, hogy hazánkban 2009-ben a foglalkoztatottak száma a tercier szektorban a legmagasabb, $64,1 \%$, majd 31,2\%-ot képvisel a szekunder szektor és végül $4,7 \%$ a primer szektor részaránya az aktív hazai munkaerópiacból. Ezzel a szolgáltató szektor majd 2,5 millió embernek biztosít megélhetést. A szolgáltató szektor egyik fényesen ragyogó ékköve az ületi tanácsadás, amely hazánkban is markánsan jelen van. Igaz, hogy a 2008-as globális válság megtörte a tanácsadó cégek ragyogását, de piacszervezó és gazdaságélénkítő funkciójuk mit sem változott.

\section{A hazai tanácsadás története}

A magyarországi menedzsment-tanácsadás ${ }^{2}$ kialakulása egy viharos korszakokkal dúsított, izgalmas történet. A történet az 1940-es évektól indul, amikor a közigazgatási racionalizációnak köszönhetően leginkább német mintára zajlott a tanácsadói tevékenység. Ezt a korszakot a II. világháború markánsan lezárta és új világ köszöntött erre a szakmára. A háború megtörte a fejlődés ütemét, hiszen olyan rés keletkezett az ideális 
és a valós állami berendezkedés között, ami jóformán kizárta az üzleti intézményrendszer fejlődését. A háború után a gazdaság szovjet mintára, tervgazdaságra épült, ami kellóképpen megágyazott a magyar tanácsadó cégek szakmai lemaradásának, a nyugati és amerikai fejlődéssel szemben (Berend, 1999). Az 50-es és 60-as évek alatt ágazati kutatóintézetek alakultak, amelyek újra elindították a tanácsadást egy felfelé ívelő pályán. Az 1968-as „új gazdasági mechanizmus” egy újabb lökést adott a szakmának, és egyre jobban előtérbe kerültek a vállalatvezetéssel kapcsolatos közgazdasági dilemmák. A 80-as évek közepén az üzemés munkaszervezők (belső és külső tanácsadók) száma megközelítette a tízezer fót (Poór, 2010). Ekkor elkezdődött az elsô vegyesvállalatok megalapítása leginkább német, osztrák és svájci piaci szereplók közremúködésével, majd a 80-as évek végére az angolszász üzleti körök is elkezdték kiépíteni tanácsadói érdekeltségeiket Magyarországon (Poór, 2010). Ekkortájt megkezdődött egy finomhangolási folyamat, hiszen a külföldi tanácsadók felvilágosult menedzsmentmegoldásai nem illeszkedtek súrlódásmentesen a magyar vállalati kultúrához. Az ezredfordulóra a betelepült nemzetközi tanácsadó cégek jelentősen megemelték a szolgáltatás színvonalát és lendületet vittek a szakma fejlődésébe. Ez a lendület a 2000-es évek „dotcom” válságának hatására egy idóre megtörni látszott, de nem lehetetlenítette el az iparágat, inkább csak újraformálta azt. A kilábalás után a haladásnak jóformán semmi nem vetett gátat egészen a 2008-as gazdasági válságig, ami jelentôs változásokat hozott a reálgazdaságban, ami áttételesen komoly visszaesést eredményezett az tanácsadói szektorban. A piac jelenleg formálódóban van, de a külföldi nagy „brand”-ek dominanciája a szerényebb magyar tanácsadó cégekkel szemben továbbra is fennáll.

\section{Helyzetkép az iparágról}

A szolgáltató szektor térnyerése révén egyre nagyobb szerepet kapnak az üzleti szolgáltatások. Tág értelemben üzleti szolgáltatásnak minősül minden olyan szolgáltatási tevékenység, amely nem a végső lakossági, társadalmi fogyasztók igénykielégítése érdekében történik. Szúkebb értelmezésben tudásintenzív üzleti szolgáltatásoknak (knowledge-intensive business service), más néven professzionális szolgáltatásoknak nevezi óket a nemzetközi szakirodalom (Papp, 2010). E szolgáltatások mögött reálfolyamatok húzódnak meg, ugyanis a tanácsadó cégek többnyire termelóvállalatoknak dolgoznak. A gazdaság dinamizmusát nagymértékben befolyásolja a termelő- és a szolgáltató szektor egybefonódott üzleti teljesítménye. A kölcsönös és egymásra utalt kapcsolat, egyfajta üzleti szimbiózis, ami a fejlődés alapját képezi. Az Amerikai Vezetési Tanácsadó Mérnökök Egyesülete (ACME) szerint „a vállalati tanácsadás egy olyan professzionális szakmai szolgáltatás, amit speciális képzettségú, megfelelố szakmai tapasztalatokkal rendelkezó szakértók végeznek annak érdekében, hogy segitsék a vezetóket a különbözó szervezetekben elóforduló vezetési, múködtetési problémák feltárásában és megoldásában". A tanácsadási tevékenységi körök közé sorolhatók a pénzügyi, adószakértői, marketing, termelési, informatikai, humán erőforrás, munkaszervezési, szervezetfejlesztési és gazdaságjogi területek.

A tanácsadó fogalom egy szinte megfoghatatlan szakmai tevékenységet fémjelez, hiszen a tanácsadó kifejezést mindenre rá lehet húzni. A tanácsadás sokszínúségét és erôsen diverzifikált szakmai tartalmát mi sem demonstrálja jobban, mint Kornai Gábornak (2008), a Vezetési Tanácsadók Magyarországi Szövetségének korábbi elnökének fantáziadús definíciója, miszerint: „Igen sokféle tanácsadás létezik: jogi, orvosi, befektetési, mérnöki, informatikai, pénzügyi és így tovább - ha nem hiszi, kérdezze meg Avon-tanácsadónójét..."

Ha jobban belegondolunk ebbe a definícióba, akkor a szellemes megfogalmazáson túl könnyedén felfedezhetjük, hogy más üzenete is van ennek a mondásnak, mégpedig az, hogy a tanácsadói piacra a belépési korlátok meglehetôsen alacsonyak, hiszen semmiféle igazolás, gépsor, tapasztalat, bizonyítvány nem szükséges a tevékenység végzéséhez. ${ }^{3}$ Ebból fakadóan bárki hívhatja magát tanácsadónak. A helyzet azért nem ennyire szomorú, hiszen ez egy komoly iparág, ahol a szakmai tudás és a kapcsolati háló erósen szelektálja a sikeres tanácsadóvá válás folyamatát.

A magyar piac adatai: (Kornai, 2008; Fisher, 2009, FEACO, 2012):

- piac mérete: 235 millió Euró (2012)

- iparági bevételek megoszlása: 2/3 versenyszféra és 1/3 közszféra

- keresleti oldal létszáma: 400-500 vállalat (megközelítőleg 4454 fő)

- igéretes területek: IT-tanácsadás, krízismenedzsment, HR outplacement

- tanácsadói óradíjak: 3000 - 350000 Ft/óra

Ebben a tanulmányban a vezetési tanácsadói tevékenységre helyezem a fókuszt. A vezetési tanácsadás vezetési kérdésekben nyújt segítséget a szervezeteknek és azok tagjainak, ami magába foglalja a probléma azonosítását, a lehetôségek felismerését és elemzését, 
a megoldási javaslatok kidolgozását és egyre gyakrabban a megoldási javaslatok véghezvitelét is (VTMSZ, 2009; Poór et al., 2000). Más megfogalmazásban egy nemzetközileg elismert szakember szerint a vezetési tanácsadók ún. tudásmunkások, akik magasan képzett szakemberek, és munkájuk jórészt abból áll, hogy az információt tudássá változtassák (Sveiby, 2001).

A tanácsadó vállalatok kategorizálását több szempontból is lehet vizsgálni. Én a Poór (2010) által képzett csoportokat tartom a legjobbnak: egyik a nyújtott szolgáltatások komplexitása szerint, a másik a méretük, piaci súlyuk szerint választja szét az egyes tanácsadó cégeket.

Ennek alapján a szolgáltatás komplexitása szerint megkülönböztethetünk:

- teljes körú tanácsadási szolgáltatást (full service firms),

- integrált tanácsadási szolgáltatást (general service firms),

- szakosodott tanácsadási szolgáltatást (specialized firms),

- erôteljesen specializált szolgáltatást (boutique firms).

És a piaci súlyuk szerinti bontás:

- mamut (PWC, Deloitte, E\&Y, KPMG, AA, IBM, Accenture),

- elefánt (McKinsey, BCG, Bain, Booz, Roland Berger, Arthur D. Little, Tata),

- oroszlán (AAM, IFUA, ICG, Concordia, Flow Csoport),

- bolha (egyéni tanácsadók, magánszakértók, mikrocégek).

A tanácsadási ágazat fejlettsége jól reprezentálja egy gazdaság fejlettségét. Ez nincs másképp hazánkban sem, ahol a magasabb GDP-termelóképességú területek köré koncentrálódnak a támogató-kiszolgáló vállalatok, hiszen itt nagyobb az igény az üzleti szolgáltatásokra. A fejlett termelővállalatok és szolgáltatócégek együtt szerves részét adják a lokális üzleti környezetnek, és ezáltal a térség fejlettségi szintjének egyaránt (Mogyorósi et al., 2009).

A PSF-ek valójában kettős tevékenységgel járulnak hozzá a nemzetgazdaság gyarapításához, mert egyszerre törekednek innoválni saját magukat, és ezzel megújulásra késztetik környezetüket, más szektorok vállalatait egyaránt (Den Hertog - Bilderbeek, 1997). Az effajta tudásbróker és tudásközvetítő vállalatok esszenciális szerepet játszanak egy gazdaság formálásában és dinamizálásában (Hipp - Grupp, 2005).

\section{A tudásmenedzsment fejlódési szakaszai}

A TM kialakulása több perióduson átívelő előrehaladás végeredményeképp tart ott, amirôl manapság beszélünk. Ennek a történeti pályának a rövid summáját Anklam (2005), David Gurteen (2008) és Noszkay (2009) kutatásai alapján mutatom be.

\section{TM 1.0 - elsó generáció}

Kezdetben a tudásmenedzsment egy informatikai megoldásnak számított, aminek a technológia állt a középpontjában. A tudást elsôsorban információs erôforrásként kezelték. A korszak TM-rendszereinek a célja a minőségi tartalomszolgáltatás volt. Adatbázisok, elektronikus dokumentumok, adattárak, on-line portálok jelentették a tudástárolás platformjait. (1. ábra)

1. ábra

Tudásmenedzsment 1.0 - elsố generáció
IT választja az eszközöket

Email, yellow pages, adattárházak

TM extra munka, inkább teher

TECHNOLÓGIAI FÓKUSZ

\section{TM 2.0 - második generáció}

A generációváltás mozgatórugója a tacit és explicit tudás gyakorlati megkülönböztetése volt, ami a humán erőforrás relevanciájának felértékelődését idézte elô. Davenport és Prusak (1998) kifejtették, hogy a kollektív szervezeti tudás elérhetővé tétele, kezelése, fejlesztése és alkalmazása a vállalat stratégiai célkitúzései között kell, hogy szerepeljenek. Az informatikai alkalmazások fejlődése lehetôséget biztosított ennek a stratégiai igénynek a kielégítésére, és az adatrögzítésról áttértek a vállalatok az új tudás előállításának a menedzsmentjére.

A módszertani fejlesztések egyértelmúen a tacit tudás mélyebb megismerését és értékteremtő funkciójának feltárását célozták. Előtérbe került a tudásgenerálás mechanizmusának megértése és ,best practice”-ek feltérképezése. Ebben a szakaszban felszínre került a motivációnak, a vezetési stílusnak és a szervezeti kultúrának a TM-rendszer hatékonyságára és eredményességére gyakorolt hatása (2. ábra). 
Tudásmenedzsment 2.0 - második generáció

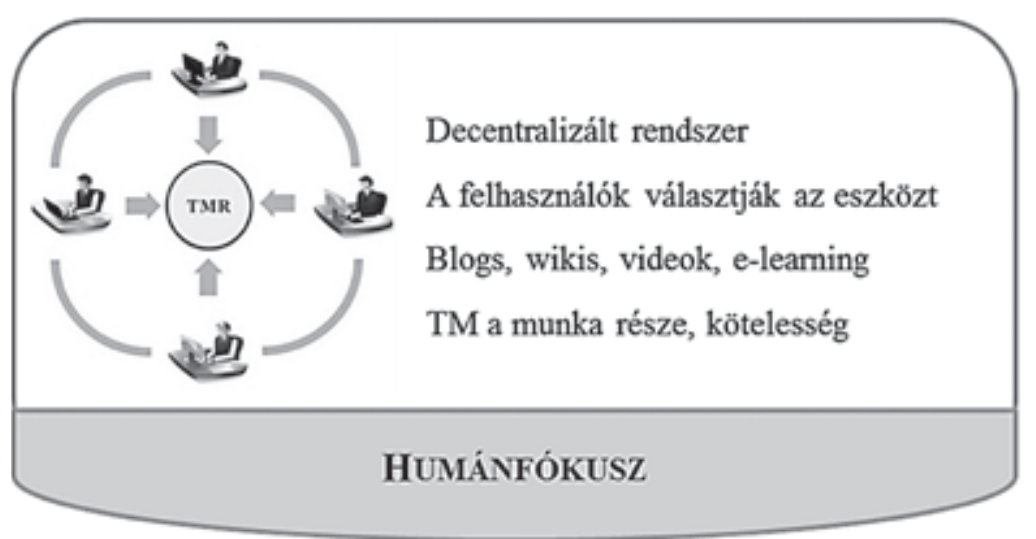

\section{TM 3.0 - harmadik generáció}

A harmadik generációt a hálózatosodás, a hálózati gazdaság felerősödése hívta életre, amikor egyértelmúvé vált, hogy a szociális hálók a vállalaton belül is fontos szerepet játszanak. A másik paradigmaváltó erő az innovációs nyomás volt, ami kikényszerítette a vállalatokból az újabbnál újabb TM-megoldások kifejlesztését és a folyamatosan változó környezethez való alkalmazkodást. Új üzleti modellek születtek, amelyek a tudásközösségek építését szorgalmazták. Ezzel párhuzamosan az intellektuális tókével kapcsolatos menedzsmentdilemmák egyre fokozták az üzleti-tudományos világ érdeklődését, hiszen a számviteli torzítások és a mérési anomáliák még mindig korlátozták a tudás hatékony menedzselését és az optimális tudásszervezet kialakítását.

A K+F és a hálózatosodás szimbiózisából elindult egy újfajta üzleti alapon szerveződő érdekközösség, amely a tudásmegosztást helyezte az együttmúködés központjába, ez volt a klaszter. Ezek a klaszterek fontos szerepet töltenek be a vállalatok közötti tudásmegosztásban. Gondoljunk itt az olasz bőr, sonkaklaszterekre vagy akár a magyar borklaszterekre (3. ábra).

Tudásmenedzsment 3.0 - harmadik generáció

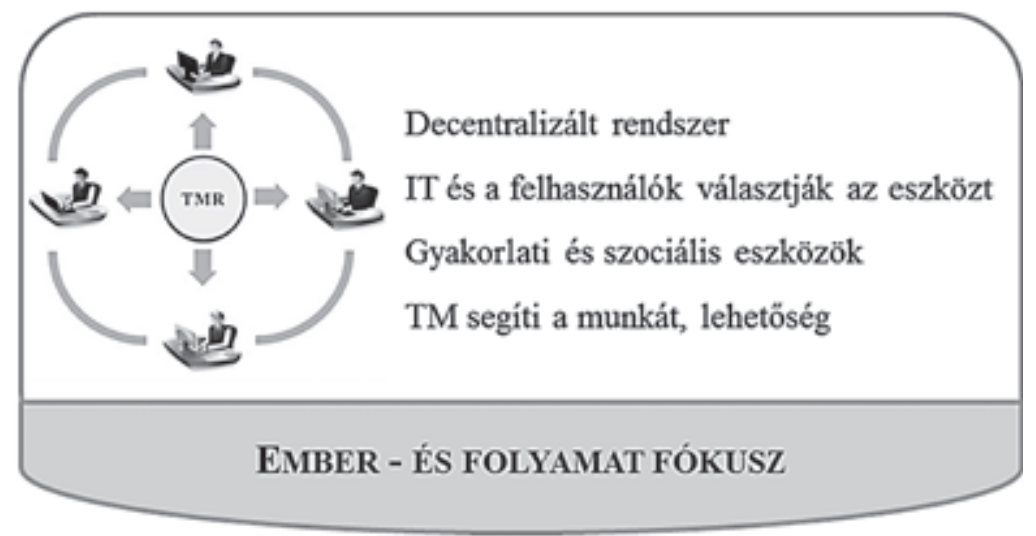

2. ábra Egyes nézetek szerint alakulófélben van a TM negyedik generációja, amely a tudást mint önálló tôkketényezôt értelmezi, és a hagyományos számviteli megjelenítésen túl egyéb mérési és menedzselési technikákat igyekszik feltárni. Ebben az új irányzatban a tudás befektetési problémaként is megjelenik, miszerint az emberbe fektetett pénz megtérülése nehezen értelmezhető üzleti szemmel, hiszen ha az illetô elhagyja a vállalatot, akkor felborul a jó előre kiszámított pénzügyi megtérülési modell. Továbbá a tudásnak mint termelési tényezőnek vannak kapacitáskorlátai, így a tudás költséggazdálkodási szempontból is meghatározó jelentőségű, hiszen a tudás túlfogyasztása ${ }^{4}$ indokolatlan költségekhez, míg a kihasználatlan kapacitás elsüllyedt költségekhez vezet. A kapacitásvonzatok és termelési tényezókön alapuló munkaszerzés modellezésében hazai kutatók élen járnak (lásd: Boda - Virág, 2010). Összegzésképp megállapítható, hogy a tudásmenedzsment intenzív elterjedése és rohamos fejlődése mögött az informatika eszköztárának bôvülése áll (Wiig, 1997), ami egyszerre hidalja át a tudás feltárásának, rögzítésének, fenntartásának, fejlesztésének, áramoltatásának, a munkafolyamatokba történô integrálásának és a szervezeti kultúrával való megbarátkoztatásának problémáit.

A TM fejlődéstörténetében még számos érdekes kérdés vethetô fel, például: minden vállalat valóban igazodott-e az egyes fejlődési szakaszokhoz, vagy nem voltak képesek olyan gyorsan alkalmazkodni, mint ahogy a vezető vállalatok? Továbbá a TM fejlődése egyben növelte a vállalat üzletmenetének hatékonyságát is, vagy csupán csak a platform és a módszerek változtak? A TM-rendszert, stratégiát és a versenyképességet övező kérdéseket igyekszem megválaszolni a továbbiakban.

$$
\text { 3. ábra }
$$

\section{Kutatásmódszertan}

Kutatásom során arra törekedtem, hogy feltárjam a magyar üzleti tanácsadó vállalatok tudásmenedzsment-gyakorlatát. A kutatás eszközéül a széles hazai és nemzetközi szakirodalmi áttekintésen túl primer kvalitatív módszertant használtam fel.

\section{A módszertan}

Az empirikus bizonyítékokat félig strukturált interjúk során gyújtöttem be. Az interjúk egy előre kiadott interjúvázlat mentén kezdődtek, majd az interjúalany tudása, hoz- 
záállása és a rendelkezésre álló idő függvényében szabad, feltáró jellegú, irányított, szakmai párbeszédbe fordultak át. Az egyes interjúk idôtartama 50-70 perc volt.

\section{A minta}

- célcsoport: 60 fónél nagyobb, markáns piaci jelenléttel rendelkezô, magyarországi üzleti tanácsadó vállalatok, amelyek egy nemzetközi tanácsadó hálózat tagjai,

- elemszám: 8 tanácsadó cég: - $4 \mathrm{db}$,full service” mamutvállalat, - 4 db szakmaspecifikus vállalat,

- interjúk száma: 14 interjú,

- interjúalanyok beosztása: széles skálán mozgott, a kutatásban részt vett tanácsadó, igazgató és partner egyaránt.

\section{A kérdöiv felépítése}

1. Tudásmenedzsment-rendszer elemei és múködése (7 db kérdés),

2. Tudásmenedzsment-stratégia feltárása (9 $d b$ kérdés),

3. Tudásmenedzsment versenyképességre gyakorolt hatása itthon és a kelet-közép- európai régióban (5 db kérdés).

\section{A kutatás korlátai}

Kutatásaim a minta nagyságából adódóan nem reprezentatív jellegúek, és nem alkalmasak a téma statisztikai módszertanokkal történô kiegészítésére. Továbbá a kutatásban részt vett vállalatok egy része hozzájárult a névvel való megjelenítéshez, másik része viszont nem, ezért úgy döntöttem, hogy a megvizsgált vállalatok kilétét nem fedem fel. Mivel az interjúk többnyire vezető beosztású tanácsadókkal, igazgatókkal és partnerekkel történtek, ezért a 14 interjú elkészítése két hónapot vett igénybe. Tágabb idôkorlátok mentén több vállalatot is be tudtam volna vonni a vizsgálódásba, ami erősítette volna a kutatás magyarországi kiterjesztését. A magyar piac méretét tekintve azonban a kutatás jelen formájában is alkalmas érdemi következtetések levonására.

\section{A kutatási eredmények}

A kutatás eredményeinek bemutatása a következő gondolati ív mentén zajlik. Először bemutatom a TMrendszer sajátosságait, majd a TM-stratégiát veszem górcsố alá, és végül a hazai és regionális versenyt taglalom. A kutatási eredmények bemutatását a kutatási kérdéstől szeretném indítani, ami így szólt:

Milyen jellegzetességek figyelhetók meg a 80 fönél nagyobb magyar üzleti tanácsadó vállalatok tudásmenedzsment-gyakorlatában a rendszert, a stratégiát és a versenyképességet illetóen?
A kérdésnek megfelelően megfigyeléseimet három csoportra osztottam, és azokon belül fejtettem ki az adott témakörhöz kapcsolódó gondolataimat.

\section{A TM-rendszer}

\section{Hogyan igazodnak a magyar tanácsadó vállalatok a TM fejlódéséhez?}

A tudásmenedzsment-szakirodalom a TM fejlődési szakainak már a negyedik generációjáról beszél, ezért szöget ütött a fejembe, hogy érdemes lenne megvizsgálni, hogy a magyar vállalatok is tartják-e a fejlődési tempót, vagy lemaradásban vannak? Az én észrevételem az volt, hogy a tudomány egy kicsit elóreszaladt a magyar állapotokhoz képest, ugyanis a hazai PSF-ek jellemzóen nemhogy a negyedik, de még a harmadik generációs TM-szemléletet és -eszköztárt sem vették át. Vannak vállalatok, amelyek élenjárnak a tudásmegosztó szervezeti kultúra kialakításában, de az ITtámogatás nem a legszínvonalasabb, és a fordítottja is előfordul. Ezt kétféleképpen lehet felfogni. Egyrészt ez egyfajta lemaradást tükröz, ami a nemzetközi versenyképességet ronthatja, ha a régiós versenytársak már felvilágosultabb módon és fejlettebb eszközökkel kezelik a szervezeti tudást.

Másrészt - az optimista hozzáállás szerint -, ez egy fejlődési potenciált jelent, ami a felfedezés után már „csupán” elhatározás, szakértelem és idő kérdése, hogy mennyi idő alatt tudnak felzárkózni a világpiaci trendekhez a magyar üzleti tanácsadók. Ez a felzárkózási folyamat egy erôforrás-igényes és hosszadalmas tevékenységsorozat, amely sok változást indukál a szervezetben. Ezeket a változásokat kezelni és menedzselni kell, annak érdekében, hogy a hatékonyabb TM-rendszerre való átállás ne okozzon zavart az üzletmenetben.

Akadtak olyan vállalatok is, akik azzal érveltek a TM-rendszer fejlettségi szintje mellett, hogy a jelenlegi rendszer azért optimális, mert egy új rendszer kifejlesztési költségei nem állnak arányban a modernebb tudásmenedzsment hatékonyságnövelő potenciáljával, így ez nem jó befektetés. Ez véleményem szerint ideig-óráig életképes reakció, de idővel a piac elhalad az ilyen vállalatok fölött, és hosszú távon versenyképtelenné teszi óket. Szerintem a tudásba fektetett pénzt hosszú távon megtérül.

A válság sajnos különösképpen kiélezi a helyzetet a befektetések körül, hiszen a fejlesztési pénzek jó részét átcsoportosították olyan tevékenységek támogatására, amelyek a túlélést segítik, példának okán üzletfejlesztés, ügyfélakvizíció, marketing. Így a TM-fejlesztések hátrébb sorolódtak a prioritási listán. 


\section{Milyen a tudásmegosztást övezố munkavállalói attitüd, motiváció?}

Egy TM-rendszernek két tetten érhetô dimenziója van, ezek pedig a bemenet (input) és a kimenet (output). Vizsgálódásaim során azt állapítottam meg, hogy a ,jobb adni, mint kapni” elv a tudásmenedzsment kapcsán egyáltalán nem múködik, ugyanis egyfajta motivációs úr van a tudásmegosztás és a tudáshoz való hozzáférés között. Ez annyit jelent, hogy az emberek abszolút tehernek élik meg, hogyha egy hosszadalmas projekt során vagy végeztével még extra idôt kell fordítaniuk arra, hogy rögzítsék a felhalmozott tapasztalataikat mások számára. A tudás előállítása jellemzően az összes vállalatnál adminisztrációs teherként csapódik le a dolgozók mindennapjaiban. Ez a jelenség alátámasztja az elóbb kifejtett fejlődésbeli lemaradást. A TM-rendszer input oldalát nem kedvelik a munkavállalók, de az output oldalát előszeretettel használják. Ezt a jelenséget én egyfajta tudásadónak neveztem el, miszerint senki sem szeret adót fizetni, de amikor felhasználóként lépünk fel a másik oldalon, akkor bizony markáns elképzeléseink vannak arról, hogy mit várunk el a befizetett összegért cserébe. Találó lehet az adóanalógia, ugyanis a be nem fizetett adó egyenló a rendszerbe be nem rakott tudással, vagyis nem járul hozzá az értékteremtéshez, a színvonalnöveléshez és a közösségi terhek viseléséhez, ezáltal a kimeneti oldal is sérül, hiszen kevesebb információt, tudást lehet kivenni a rendszerből. Tehát ha nem fizetünk adót, akkor ne is várjunk magas színvonalú szolgáltatásokat cserébe, és ha nem fizetünk tudásadót, akkor ne várjuk a munkafolyamatok lerövidülését, a szakmai fejlódést és a közösséghez való tartozás érzését sem.

A megfelelő motivációs szint kialakítása nagy menedzsmentkihívás, hiszen enélkül nem múködóképes a rendszer. Azonban látni kell, hogy ma még a szervezeti tagok túlnyomó része a munkával járó teherként tekint a tudásmegosztás intézményére, ami jelentôsen viszszaveti a rendszer hatékonyságát és esetenként az input minőségét is.

Még ha motivált is a felhasználó a tudásmegosztásban, akkor is akadnak korlátozó tényezók. A TM diszfunkciói között figyeltem fel arra a dilemmára, hogy bárki, bármikor hozzáfér a rendszerhez, de arra semmiféle garancia nincs, hogy miként értelmezi az adott anyagot, egyszóval értelmezési hiányosságok torzíthatják a rendszer hatékonyságát.

A motiváció gondolatkörének zárásaképp egyik interjúalanyomtól szeretnék idézni:

„Az egyéni tanulás, önfejlesztés nem igény és motiváció kérdése, hanem alapkövetelmény, egyfajta szakmai minimum."

\section{A TM-stratégia \\ Mi jellemzi a magyar tanácsadó vállalatok TM-stratégiáját?}

$\mathrm{Az}$ elméleti részben nevesített TM-stratégiák szinte mindegyikét felfedeztem a vizsgált vállalatok körében: van, amelyik kodifikációs, van, amelyik perszonalizációs és akad, amelyik vegyes stratégiát alkalmaz. Az elsố kettố nem olyan érdekes, hiszen Hansen, Nohria és Tierney (1999) alaposan kidolgozta e stratégiák jellemzóit, de a vegyes TM-rendszerekról már kevesebb szó esett. Véleményem szerint a vegyes TM-rendszerek sokkal nagyobb komplexitást mutatnak a másik két szélsôséghez képest. Ez nem csoda, hiszen a kettő kombinációjáról van szó, így a vegyes stratégia célja, hogy ötvözze a két ellentétes pólus hasznos módszertanait. Nyilvánvalóan ez egy összeférhetetlenségi problémát fog eredményezni, ezért valamilyen szinten el kell köteleződni az egyik véglet mellett, és egészséges mértékben be kell emelni addicionális elemeket a másik stratégiából, így kialakítva a stratégia optimális összetételét. A vegyes stratégia lényege, hogy szolid, nem túl költséges IT-támogatással egyfajta ráutaló magatartást ösztönöz, ami arra irányul, hogy az információgazda és az információfelvevô rátaláljanak egymásra. A keresési szakaszban az IT a hangsúlyos, majd az információátadási szakaszban a személyes interakciók dominálnak. A hibrid stratégiát követő vállalatoknál jellemzóbb, hogy elkülönült szervezeti egység koordinálja a tudásmenedzsmentet, amely egység élén $\mathrm{CKO}^{5}$ van. Ez a jelenség demonstrálja a TM-funkcióra fordított figyelem mélységét. Ebbe beletartozik a TM-stratégia is. A stratégiai szintre emelt TM-funkció egy dinamikus szerepben van, hiszen folyamatos kétirányú fejlesztésnek van kitéve. Az egyik fejlesztési irány az IT- (infrastrukturális), a másik a szakmai (tartalmi) fejlesztés. Ideális esetben a stratégia egyszerre kezeli mindkét területet és rögzíti a vállalat céljainak megfelelő TMfejlesztési arányokat. Kutatásaim rávilágítottak, hogy az írott TM-stratégia terén elég színes vállalati gyakorlatokkal találkozhatunk. Van, ahol meglehetôsen komoly, ábrákkal, szakmai modellekkel, folyamatábrákkal tû́zdelt, teljes körú és nagyon vállalatspecifikus TMstratégia létezik, ami egyértelmúen visszaadja a vállalat alapértékeit, misszióját és jövớképét. A másik véglet a TM-stratégia teljes hiánya, ebben az esetben a TM-mel kapcsolatos célok és döntések csak bizonyos kulcsszereplók fejében léteznek. Az viszont biztos, hogy kicsi a korreláció a TM-stratégia formalizálása és a vállalat üzleti sikerei között. Ez egy paradox jelenség, mert a közgazdaságtan úgy szereti a stratégiát, ha az le van írva és formálisan is közzétehető, úgymond lehessen muto- 
gatni. Azonban egy üzleti tanácsadó vállalat annyival könnyebb helyzetben van egy átlagos versenypiaci társasággal szemben, hogy a tudásmunkások tisztában vannak a stratégia jelentőségével, és elképzelhető, hogy a vállalati kultúra és a munka során kialakult rutinok folyamatosan hozzájárulnak az informális TM-stratégia megvalósulásához, így a formalizálás hiánya nem csökkenti a stratégia megvalósításának lehetőségét.

\section{Léteznek-e tudásmenedzsment-hálózatok Magyarországon?}

Kutatásaimra alapozva kijelenthetem, hogy abszolút léteznek. A nagy nemzetközi tanácsadó cégek magyarországi leányvállalatai általában az anyacég tudásmenedzsment-rendszerének integráns részei. Ez a kapcsolat állandó jellegú és igen hasznos, hiszen az adott vállalatcsoport összes tagja hozzáfér a tagok egyéni kompetenciáihoz, illetve a rendszerben rögzített anyagaihoz. A nemzetközi hálózat ereje tehát abszolút érvényesül azáltal, hogy a vállalatcsoport tagjai akár olyan munkára is tudnak pályázni, amire nincs meg a lokális szaktudás, mert amennyiben elnyerik a megbízást, a nemzetközi hálózatból - egy projekt erejéig - kirendelik a szakértőket a nemzetközi színtérre. Ezzel a technikával növelhetik a vállalat szakmai portfólióját és a megbízások számát. Ez a tudáshálózat az én olvasatomban kétféleképpen jellemezhetô: globális, mert az összes leányvállalat használja a rendszert, így az összvállalati tudás kumulálódik, valamint univerzális, mert mindenhol ugyanaz a felület van, aminek köszönhetően a vállalatcsoport összes felhasználója rutinosan tudja használni a rendszert. A hálózati gazdaság egyik nagy előnye a kollektív tudásplatformok kialakítása, kiaknázása és folyamatos fejlesztése.

Milyen kapcsolat van a tudás és az innováció között?

A stratégia boncolgatása során sok interjúalanyom kitért arra, hogy a tudásmenedzsment-stratégia alapvető célja, hogy serkentse a szervezeten belüli innovációt. Az innováció azért kap kiemelt szerepet, mert az új ötletek, az új menedzsmentmegoldások mind megkülönböztető erővel bírnak a piacon, így versenyelőnyhöz juttathatnák az adott vállalatot. Az innovációs hajlam és az újító szellem a szellemi munka egyik alapvetô sikertényezője, hiszen a gondolkodás és a változás képessége kimeríthetetlen kapacitásokat jelent a vállalat számára. Sajnos az interjúalanyok azt is hozzátették, hogy a szúkülő gazdasági térben nem egyszerú az új ötleteket eladni, hiszen a megrendelók sokszor a már jól bevált, megszokott tartalmakat rendelik meg, és félnek az újítással járó kockázattól, ami egyaránt jelent üzleti, múködési, illetve anyagi jellegú rizikót. Ilyen gazdasági környezetben, telített piacon senki nem sze- ret a „kísérleti nyúl” szerepébe bújni és maga mögött hagyni a kiforrott megoldásokat, ami egyfelól érthető reakció a válságra és a pénzszúkére, másfelól pedig egy lehetőség megvonása a vállalattól. Az innovációval az a legnagyobb baj, hogy egy új szervezeti módszertan hatékonyságát, eredményességét nehéz kimutatni az ügyfélnek, ebból az következik, hogy a nehezen monetarizálható termékek és szolgáltatások kevésbé piacképesek, és nagyobb kockázatot jelentenek a tanácsadónak és az ügyfélnek egyaránt. Sajnálatos módon recesszió idején nincs nagy igény az innovációra, mert a megbízók jobban szeretik azokat a jól bevált módszertanokat, amelyeknek történetileg megalapozott és igazolható eredményeik vannak. Félnek az újításoktól, így a menedzsmentinnovációk szerepe is hátrasorolt tényezővé válik a tanácsadó cégeknél. Az innovációval kapcsolatban a végszó tehát: dekonjunktúrában a bevett módszertanok ereje nagyobb, és fejlődési időszakban pedig újból felerôsödik az innováció iránti igény.

Szintén egy idézettel szeretném zárni ezt a témakört:

„Recesszióban a megszokott módszertanok új ötletekkel való vegyítésében nyilvánul meg leginkább az innováció.”

\section{A TM és a versenyképesség}

\section{Versenyképes-e a magyar tanácsadói szolgálta- tás regionális szinten?}

Az elốbb említett hálózatos tudásmenedzsment-rendszernek, valamint a munkavállalók magas szakmai képzettségének köszönhetően az üzleti tanácsadási szolgáltatások általánosságban véve versenyképesek a nemzetközi piacokon is. Regionális, sốt globális szinten is versenyképesek ezek a vállalatok, mert alapvetően tudást adnak el, aminek a közös tudásbázis a forrása. A projektekhez szakértôket rendelnek ki, így a megrendelő biztos lehet abban, hogy a legjobb szaktudású kollégák végzik el a munkát, még akkor is, ha azok idegen országból jönnek.

Összességében elmondható, hogy van korreláció a tanácsadó cégek versenyképessége és a tudásmenedzsment színvonala között, de leginkább a nemzetközi hálózat hozhat új, határokon átnyúló üzleteket. A nemzetközi versenyképesség elsődleges forrása a hálózathoz való tartozás és a hálózat szakmai berkekben elterjedt hírneve.

\section{Mi a tudás szerepe válság idején?}

Egybehangzó választ kaptam arra a kérdésre, hogy mi a tudás szerepe válság idején. A válasz pedig az, hogy a tudás az egyetlen kiút a válságból. A humánbefektetések és a tudásmenedzsment folyamatos fejlesztése mára már nem versenyelőnyt biztosító tevékenységek, csupán a versenyben maradás feltételei. 
A hazai tanácsadó cégek TM-evolúciója

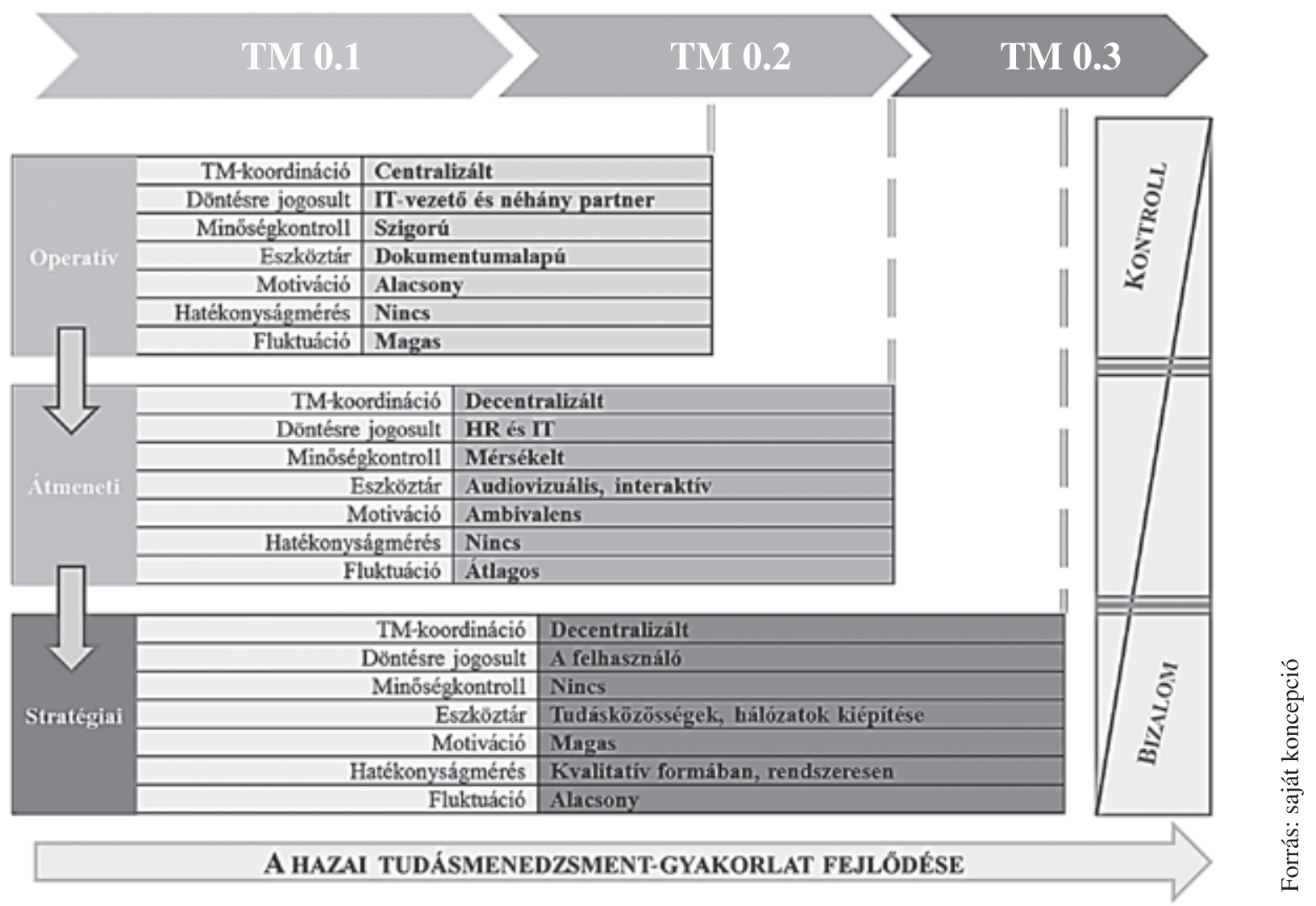

Az egyik vezetô ezt úgy világította meg, hogy egy ötmillió forintos többletbevételt inkább egy háromnapos tréningre fordít, minthogy kiossza prémiumban, ugyanis ezzel sokkal több értéket teremt a munkavállalóknak, és ezáltal áttételesen a vállalatnak és érintettjeinek. Ez rövid távon lehet, hogy kellemetlenül érinti a munkavállalókat, de hosszú távon egyértelmúen profitálhatnak belóle akár egyéni, akár szervezeti szinten, és mint tudjuk, a tudás hosszú távú befektetés.

\section{Melyek a tanácsadói piac új trendjei?}

A rendszerváltással a hermetikusan zárt közép-európai tanácsadói piac felszabadult és útnak indult a határon átívelő üzleti tranzakciók sorozata. A szovjet kötöttségek lerázása hatalmas lendületet adott a tanácsadói piacnak, amely lendület kisebb-nagyobb kilengésekkel egészen a 2008-as gazdasági világválságig fennmaradt. A 2008-as krízis korszakhatár volt a világban, ami egy tartós recessziós közeget hozott létre. Magyarországot sem hagyta érintetlenül ez a gazdasági visszaesés, így szúküilésnek indult a reálgazdaság, az infláció erôsödött, megszúnt a pénzbőség. A bizonytalan gazdaságipolitikai környezet forgácsolja a hazai piacokat, így a benne múködő vállalatokat is. Ennek a gazdasági me- chanizmusnak köszönhetően szúküilt a tanácsadói piac: a gyengék kiestek, a nagyok leépítettek és a nemzetközi cégek tovább növelték dominanciájukat a hazai tanácsadó cégekkel szemben. A piacon újraformálódás figyelhetô meg, aminek a kimenetele még nem látható előre.

Egyik interjúalanyom az alábbi módon fogalmazta meg a válságból való kilábalás stratégiáját:

„Csak a humántóke-befektetések jelentenek megoldást a válságban. Túl kell lépni a hagyományos módszereken és „Blue Ocean” stratégiát kell követni, ebben van a jövó. Lehetôség az új ügyfél-új termék kombinációk kiépítésében és az igényekhez folyamatosan igazodó, rugalmas, szakértói teamek felállításában van."

\section{Összkép a hazai tanácsadó vállalatokról}

A 4. ábrában aggregáltam a kutatási tapasztalataimat, ami tovább fejti a kutatási kérdést és bemutatja, milyen a hazai üzleti tanácsadó vállalatok tudásmenedzsmentgyakorlata. A kutatási eredményeim alapján, a saját interpretációmban a hazai vezetési tanácsadó cégeket az alábbi három fejlettségi szintbe lehet besorolni.

A 4. ábra jól visszaadja a hazai valóságot, hiszen akadnak olyan tanácsadó cégek, amelyek a régi

\section{VEZETÉSTUDOMÁNY}


„command \& control”“ stílusú tudásmenedzsmentben hisznek. Ezek a lemaradók vagy sereghajtók, akik inkább a szellemi termékek rögzítésére helyezik a hangsúlyt és az „agyleszívás” stratégiáját követik, hogy ezzel csökkentsék a fluktuáció által bekövetkezett tudáskiáramlást. Ebból is látszik, hogy fontos funkció a TM, de korántsem stratégiai szinten kezelik a kérdést. A választott tudásmenedzsment-stratégia sokszor a vállalati profil függvénye, ugyanis van olyan eset, amikor az alaptevékenység nem kívánja meg a tudás továbbfejlesztését, hanem megelégszik a standardizált tudás továbbadásával. Ez a szint legtöbbször a standardizált szolgáltatásokat nyújtó, nagy könyvvizsgáló és adótanácsadó vállalatokra jellemzô.

Az egy fokkal fejlettebb tanácsadó vállalatok, akik nagyobb szabadságfokkal múködtetik a tudásmenedzsment-rendszert, rájöttek a decentralizációban és az alkotói szabadságban rejlő potenciál hasznosítására. Ebben a szakaszban a legnagyobb kihívás a munkavállalók motiválása, mert azok nem tudják eldönteni, hogy csupán idôközönkénti hatékonyságnövelési törekvés a TM, vagy egy állandó, a gazdálkodás szerves részét képezô értékteremtő funkció. Erre a szakaszra jellemző a választékosabb eszköztár és a humán faktorok felértékelődése, valamint a stratégiai szemléletmód erôsödése. Ezt a szintet az egyedibb szolgáltatásokat nyújtó vállalatok reprezentálják, ahol többnyire a vezetési tanácsadás stratégiai, IT, tranzakciós és pénzügyi része a dominánsabb.

Kutatásaim során azt figyeltem meg, hogy a legfejlettebb vállalatok a harmadik generációs tudásmenedzsment-elemek egy részét már elkezdték használni és beépíteni a mindennapi múködésbe. A tudásmenedzsment a „,command \& control” stílusról abszolút „communication \& cooperation”7 stílusra váltott. Ennek egyfajta üzletfilozófiai alapja is van, hiszen a munkavállalók egészen addig nem tudnak azonosulni a szervezeti célokkal, amíg nem hisznek bennük. Ezen a szinten már közelednek a vezetôi és a munkavállalói érdekek, így egy közös gondolkodásmód alakul ki, közös ösvényre lépnek, amely ösvény nem más, mint az értékteremtés útja. Az információk feldolgozása nem felülrôl irányított, ezáltal a tudásmunkások önirányítóbbak, ami serkenti az innovativitást, az önkifejezést, a munkamorált, ugyanakkor növeli a hibás döntések kockázatát, a felületes tervezést, a szabadsággal való visszaélést. Éppen ezért a harmadik generációs tudásmenedzsment mozgatórugója a kölcsönös bizalom. Ezt a szakaszt a motiváció, a célegyezôség, a munkavállalói szabadság, a felelősségteljesebb munkavégzés, az alkalmazotti húség és a teljesítménynövelés jellemzi. Hozzávetôlegesen tovább növeli a rendszer fejlettségi szintjét az önértékelés - teljesítménymérés - javadal- mazás hármas, ami egyszerre érezteti a munkavállalóval, hogy fontos szervezeti tag, továbbá visszajelzéseket kap a munkájáról és annak minőségérôl, amihez kiemelkedő teljesítmény esetén többletjövedelem társul. Ezenfelül személyes fejlődési irányokat jelöl ki a rendszer, hogy fenntartsa a pozitív attitúdöt és egyfajta jövőképet, perspektivikus gondolkodást adjon a tudásmunkásnak. Az ebben a fejlődési szakaszban levô vállalatok stratégiai szinten már helyén kezelik a tudásmenedzsmentet. Gyorsan hozzá is teszem, hogy ez csupán nagyon kevés vállalatra jellemzô, inkább a réspiacokat kiszolgáló, néhány szakterületre vagy iparágra koncentráló tanácsadó cégek helyezik stratégiai szintre a TM-et, hiszen a speciális tudás megszerzése és továbbfejlesztése számukra a versenyelőny kardinális része, nem beszélve a fluktuáció alacsonyan tartásáról.

A szakaszok közti különbség a rendszer sebezhetőségében, az idôtávban és a bizalomban gyökerezik. Amint láttuk, minél elavultabb TM-filozófia szerint vezetik a cégeket a menedzserek, annál ,poroszosabb” módszereket használnak, így az alacsony szabadságfok és a jól nyomon követhető munkavállalói tevékenység csökkenti a vállalati sebezhetőséget. Ahogy haladunk a fejlettebb megoldások felé, úgy csökken a kontroll, ezzel átadva a helyet a bizalomnak. Annak a bizalomnak, ami semmiképpen sem fog rövid távon radikális eredményeket hozni a szervezetnek. A fejlettebb TMstratégiák egy koherens, könnyen kezelhető rendszert múködtetnek és türelmesen várják, hogy igazi értékalkotó tudásközösségek és szervezeti memória épüljön ki egy öngerjesztô folyamat végeredményeképp. Az egyre növekvő munkavállalói szabadság elősegíti ezt a folyamatot. Ezzel szemben az elsô és a második generáció rövid és középtávra tervez, a tudásmenedzselésból gyorsan szeretne profitot látni, hiszen a tudásmenedzsment tôkebefektetésnek minôsül, így pénzügyileg racionális feltételezés, hogy megtérülést is várunk a TM-tôl. Ez a rövid távú koncepció eleve felemészti a bizalomhoz vezető utat, hiszen a közgazdasági racionalitást keresi a rendszerben. Véleményem szerint rövid és középtávon a „homo socionomicus” szemléletmód a célravezetó, és nem pedig a „homo economicus”, mert a gazdasági hozzáadott érték jelentkezni fog, ha alaposan meg van ágyazva a sikeres üzletmenetnek, de ahhoz, hogy a szervezeti tagok, a tudáshalmazok és a kollektív képességek egybeérjenek, időre van szükség. Ezalatt célravezetóbb, ha a vezetók és a tulajdonosok nem profithajhász és haszonmaximalizáló viselkedésmintát követnek, hanem érző emberi lényként segítik a szociális hálók és a szakmai közösségek gyarapodását, és nem csupán egy kimeríthetetlen pénzeszsákot képzelnek az emberek helyébe. 


\section{Összefoglalás}

A kutatás egyértelmúvé tette a tudásvállalatok fokozódó térnyerését és gazdaságformáló szerepét. Továbbá nyilvánvalóvá vált, hogy a tudásmenedzsmentnek elvitathatatlan érdemei vannak az üzleti tanácsadó vállalatok sikeres múködésében. Ezt a múködést három részre bontva vizsgáltam: rendszer, stratégia és versenyképesség szintjén. A munka során az az összkép alakult ki bennem a magyar vezetési tanácsadók tudásmenedzsment-gyakorlatáról, hogy komoly szakmai munka folyik a vizsgált vállalatok mindegyikénél, azonban kivétel nélkül van még továbbfejlődési lehetôség a tudás menedzselése terén. Ez többnyire a változó fogyasztói igényeknek, az informatikai megoldások dinamikus fejlődésének és a piacok globalizálódásának tudható be.

A tanulmány hozzáadott értéke a stratégiai szemlélet elmélyítésében és az aktuális kérdések vezetôi aspektusból történő kifejtésében - mint válság, innováció, motiváció - van. A dolgozat jól tükrözi a magyar valóságot, azt a követő magatartást, miszerint a vállalatvezetók tisztában vannak a TM lehetséges kiterjesztési és fejlesztési irányaival, de a pénzügyi erőforrások és az egyre erôsödő verseny elsorvasztják az arra irányuló törekvéseket. Árnyalja ugyan a képet, hogy recessziós környezetben nem olyan könnyư döntés a tudástóke-befektetés, de úgy gondolom, ha a gazdaság visszaáll a növekedési pályára, akkor a magyar üzleti tanácsadó vállalatok tudni fogják, hogy milyen irányú fejlesztésekkel érdemes modernizálni a tudásmenedzsment-rendszerüket.

Ami a jövôt illeti, az iparági elôrejelzések szerint a következő években világviszonylatban az egészségügyi, az energetikai és a környezetvédelmi szektor fogja adni a kereslet húzóerejét. Ennek köszönhetően a versenyképességet az ezekben az iparágakban való jártasság döntően befolyásolhatja (Datamonitor, 2009). Véres árháború, minôségromlás, kivonulás, felvásárlás, piaci konszolidáció, újraformálódás, rejtély, hogy mit hoz a jövő a tanácsadói iparágban.

\section{Lábjegyzet}

${ }^{1}$ KSH-adatok alapján, Papp Ilona (2010) szolgáltatási menedzsment

${ }^{2}$ A tanulmányban a menedzsment-tanácsadó, üzleti tanácsadó, vezetési tanácsadó, PSF (Professional Service Firm) kifejezéseket szinonimaként használom.

${ }^{3}$ Az igaz, hogy nincs kötelező előírás a tanácsadók elóképzettségéról és szakmaiságáról, de lehetőség van a professzionális tanácsadók kiszúrésére, ugyanis a Vezetési Tanácsadók Magyarországi Szövetsége (VTMSZ) az International Councilof Management Consulting Institutes (ICMCI) magyarországi akkreditált tagszövetségeként végzi a hazai vezetési tanácsadók $\mathrm{CMC}$-minősítését. A CMC-minősítés (Certified Management Consultant) olyan vezetési tanácsadót takar, aki megalapozott szakmai ismeretekkel rendelkezik, elfogadja és alkalmazza a szakma etikai elveit. A CMC-minősítés megszerzésére évente egyszer van lehetőség. Megszerzésének előfeltételei között szerepel az egyetemi vagy fő- iskolai végzettség és a legalább ötéves, fó tevékenységként végzett vezetési tanácsadói tapasztalat.

${ }^{4} \mathrm{Pl}$. ha egy egyetemi szemináriumot egy professzor tart, amikor egy tanársegéd is meg tudná tartani az órát (ekkor ugyanazt a feladatot más hierarchiaszinten dolgozó, más bérezési kategóriába esô munkaeró látja el).

${ }^{5}$ Chief Knowledge Officer $=$ tudásmenedzser, fejlesztési vezető

${ }^{6}$ „Utasítás és irányítás”, autokratikus vezetési stílusra vall.

„,Kommunikáció és együttmúköódés”, demokratikus vezetési stílusra vall.

\section{Felhasznált irodalom}

Anklam, P. (2005): The social network toolkit: Building Organisational Performance through Collaborative Communities. London: Ark Group

Berend T. I. (1999): Terelőúton, Közép- és Kelet-Európa, 1944-1990. Budapest: Vince

Boda Gy. - Virág I. (2010): Ütemvakság. Közgazd. Szemle, X.

Datamonitor (2009): Company Profile. The Boston Consulting Group, 15. October 2009.

Davenport, H.T. - Prusak, L. (1998): Working Knowledge. Boston: Harvard Business School Press

Den Hertog, P. - Bilderbeek, R. (1997): The new knowledge infrastructure: the role of knowledge-intensive business in national innovation systems. in: Miles, I. (Ed.): Services, Innovation and the Knowledge-based Economy. London: Routledge

FEACO (2012): http://www.feaco.org/sites/default/files/sitepagefiles/Feaco\%20Survey\%202011-2012.pdf (1.: 2014. 10. 11.)

Fischer, P. (2009): Saving on the smarts? Budapest Business Journal, Október

Gurteen, D. (2008): http://zyxo.wordpress.com/2008/12/28/ km-10-km-20-km-30/ (Letöltve: 02. 02. 2012)

Hansen, M. - Nohria, N. - Tierney, T. (1999): What's Your Strategy for Managing Knowledge? Harvard Business Review, Mar-Apr: p. 106-116.

Hipp, C. - Grupp, H. (2005): Innovation in the service sector: The demand for service-specific innovation measurement concepts and typologies. Research Policy, Vol. 34: p. 517-535.

Kornai G. (2008): Vezetési tanácsadás. Napi Gazdaság, 2008. december 4.

Mogyorósi P. - Bucsai K. - Hornyák Zs. - Tyetyák Zs. (2009): Az üzleti tanácsadási ágazat jellemzőinek és innovációs modelljének felvázolása. Budapest: MISZ

Noszkay E. (2009): A tudásmenedzsment hazai fejlődéstörténete. in: Vezetési ismeretek III. - Tanulmányok a társtanszékek munkatársaitól Sz.: Veresné dr. Somosi Mariann, Jubileumi Kiadv.. Miskolci Egyetem: p. 124-187.

Papp I. (2010): Szolgáltatási menedzsment. Bp.: Aula Kiadó

Poór J. (2000): Menedzsment tanácsadás kézikönyv. Budapest: KJK Kerszöv

Poór, J. (2010): Menedzsment-tanácsadási kézikönyv. Budapest: Akadémia Kiadó

Sveiby K. E. (2001): Szervezetek új gazdasága: A menedzselt tudás. Budapest: KJK Kerszöv Kiadó

Wiig, K.M. (1997): Knowledge Management: Where did it come from and Where will it go? Expert Sytems With Applications, 13: p. 1-14. 